\title{
WHICH MOON PHASE DO WE FIND MORE GHOSTS? EFFECTS OF THE LUNAR CYCLE ON THE GHOST CRAB Ocypode quadrata (FABRICIUS, 1787)
}

\author{
Em que fase da lua encontramos mais fantasmas? \\ Efeitos do ciclo lunar no caranguejo fantasma \\ Ocypode quadrata (Fabricius, 1787)
}

\author{
Matheus Oliveira Fortaleza ${ }^{1 *}$, Magalline Maria Lemos Girão², Wilson Franklin Junior³, \\ Jadson Pinto de Lima ${ }^{4}$, Cristina de Almeida Rocha-Barreira ${ }^{5}$ \\ ${ }^{1}$ Pós-graduação em Ecologia e Conservação, Universidade Federal Rural do Semi-Árido (Ufersa/RN) \\ 2Instituto de Ciências do Mar, Universidade Federal do Ceará, Fortaleza, Brazil \\ ${ }^{3}$ Laboratório de Zoobentos, Instituto de Ciências do Mar, Universidade Federal do Ceará \\ ${ }^{4}$ Laboratório de Zoobentos, Instituto de Ciências do Mar, Universidade Federal do Ceará \\ ${ }^{5}$ Laboratório de Zoobentos, Instituto de Ciências do Mar, Universidade Federal do Ceará \\ *E-mail for correspondence: matheusoliveira@gmail.com
}

\begin{abstract}
The ghost crab Ocypode quadrata is commonly found in the middle and supralittoral areas of sandy beaches along the Brazilian coast. It is a known and important species in the ecology of beaches, which inhabit semi-permanent burrows excavated, maintained, and protected by them. This study evaluated the density and diameter of $\mathrm{O}$. quadrata burrows, considering three lunar cycles in a Conservation Unit on the coast of Ceará state, Northeastern Brazil. Quarterly samplings were performed between 2014 and 2015 during the early morning in the four phases of the moon over three lunar cycles. The tidal range (high tide and low tide) and nocturnal luminosity were used to evaluate the effects of the lunar phases on crab behavior. The lunar cycles influence the activity of the O. quadrata, varying the density, diameter, and distribution of the burrows along the beach, due to changes in the tide conditions and nocturnal luminosity. The construction of burrows by the crabs was higher in the moons that provided more bright nights.
\end{abstract}

Keywords: ghost crab, burrows, Canto Verde beach, phases of the moon.

Recebido em: 18/11/2019

Aprovado em: 21/1/2019

Publicado online em: 20/3/2020 


\section{RESUMO}

O caranguejo Ocypode quadrata é encontrado comumente no médio e no supralitoral de praias arenosas oceânicas ao longo do litoral brasileiro. É uma espécie reconhecidamente importante na ecologia de praias, habitando tocas semipermanentes escavadas, mantidas e protegidas pelos próprios animais. Este estudo avaliou a densidade e o diâmetro das tocas de O. quadrata, considerando três ciclos lunares em uma unidade de conservação no litoral do Ceará. Foram realizadas amostragens trimestrais entre 2014 e 2015, no início da manhã, durante as quatro fases da lua ao longo de três ciclos lunares. As variações de maré (altura da preamar e baixamar) e luminosidade noturna foram utilizadas para avaliar os efeitos das fases lunares na praia do Canto Verde. Os ciclos lunares influenciam na atividade do caranguejo O. quadrata, variando a densidade, o diâmetro e a distribuição das tocas abertas ao longo da praia, em função de mudanças das condições de maré e luminosidade noturna. A ocorrência de construção de toca dos caranguejos foi maior nas luas que proporcionam noites mais iluminadas no ambiente.

Palavras-chave: caranguejo-fantasma, tocas, praia do Canto Verde, fases da lua.

\section{INTRODUCTION}

The activities of several decapod crustaceans, such as crabs, are influenced by environmental factors, and the lunar cycle is one of the main drivers to variations in such activities due to fluctuation in tidal range and variations in night light on the beach. While the full moon provides the highest values of night light intensity, the new moon provides the lowest value. The first quarter and last quarter moon provide intermediate values (Oliveira Filho \& Saraiva, 2014).

The light perception in crustaceans is mainly due to the ommatids, which is located in the ocular peduncle of the optical lobe. Welsh $(1939,1941)$ suggests that the location of the protective pigments of the crystalline lens inside the ommatids varies in a circadian rhythm, in which during the dark phase the pigments expose more the light receptors while during a light phase, they protect them more.

Crabs of the genus Ocypode, also known as ghost crabs, are substantially common organisms of macrobenthic fauna of tropical and subtropical sandy beaches worldwide (Mclachlan \& Brown, 2006). In Brazil, the genus Ocypode is represented by a single species, Ocypode quadrata (Fabricius, 1787), which inhabit the supralittoral, building its burrows from the mark of the high tide waterline to the dune area. They spend most of their lives in burrows that shelter them from adverse climatic conditions, predators, and serve as a refuge during mating, molting, and egg incubation process (Chan et al., 2006; Schober \& Christy, 1993).

Such crabs alternate activities between the surface of the beach (eg. foraging, and maintenance of burrows) and their underground microhabitat (Lucrezi \& Schlacher, 2014). Different patterns of activity have been observed for O. quadrata concerning the period of the day in which these animals are most active. Alberto and Fontoura (1999) and Pombo et al. (2017) have demonstrated that variations in temperature, tides, and other environmental variables such as wind intensity and level of reach of the waves influence the activity pattern of such crabs. 
According to Steiner and Leatherman (1981) and Blankensteyn (2006), O. quadrata presents an intense nocturnal activity, remaining inside its burrows during the day. However, Valero-Pacheco et al. (2007) reported that individuals of such species are active most time of the day with high activity peaks at sunrise and sunset. Although studies have already reported the influence of the semilunar phases on the behavior of decapods, mainly related to larval release activities during the full and new moon, which have a higher tidal range (Forward \& Richard, 1987), information of such influence on Ocypode quadrata is still incipient. This information is fundamental to the comprehension of variations of ghost crabs behavior, such as oscillations of the quantity and size of the individuals of a population, frequency of burrows maintenance, periods of greater activity and distribution over the beach.

Thus, due to the variations of tidal range and the night light that reach the beach, the present research aims to evaluate the variation in the frequency of the burrow maintenance activity over the lunar phases. In this way, density and size of O. quadrata burrows were assessed during three lunar cycles on a sandy beach located in a protected area in Northeast Brazil. Furthermore, regarding the conservation status of such species, this analysis presents an important contribution to the population study since the prior knowledge of the natural population's behavior in protected areas can provide considerable bioindicator parameters.

\section{MATERIAL AND METHODS}

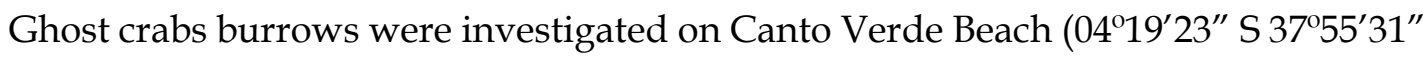
W) on the east coast of Ceará state, $120 \mathrm{~km}$ far from the capital city Fortaleza (Figure 1). Such beach is a Federal Conservation Unit (FCU), categorized as Extractive Reserve, comprising an area of $297.9 \mathrm{~km}^{2}$ of land and sea environments. Thus, the low anthropic interference on the region that is inhabited by the population of $O$. quadrata allows attributing the results to the natural behaviors of the species and not in response to environmental disturbances.

Figure 1 - Location of Canto Verde beach, Beberibe Municipality, Ceará state, Northeast, Brazil

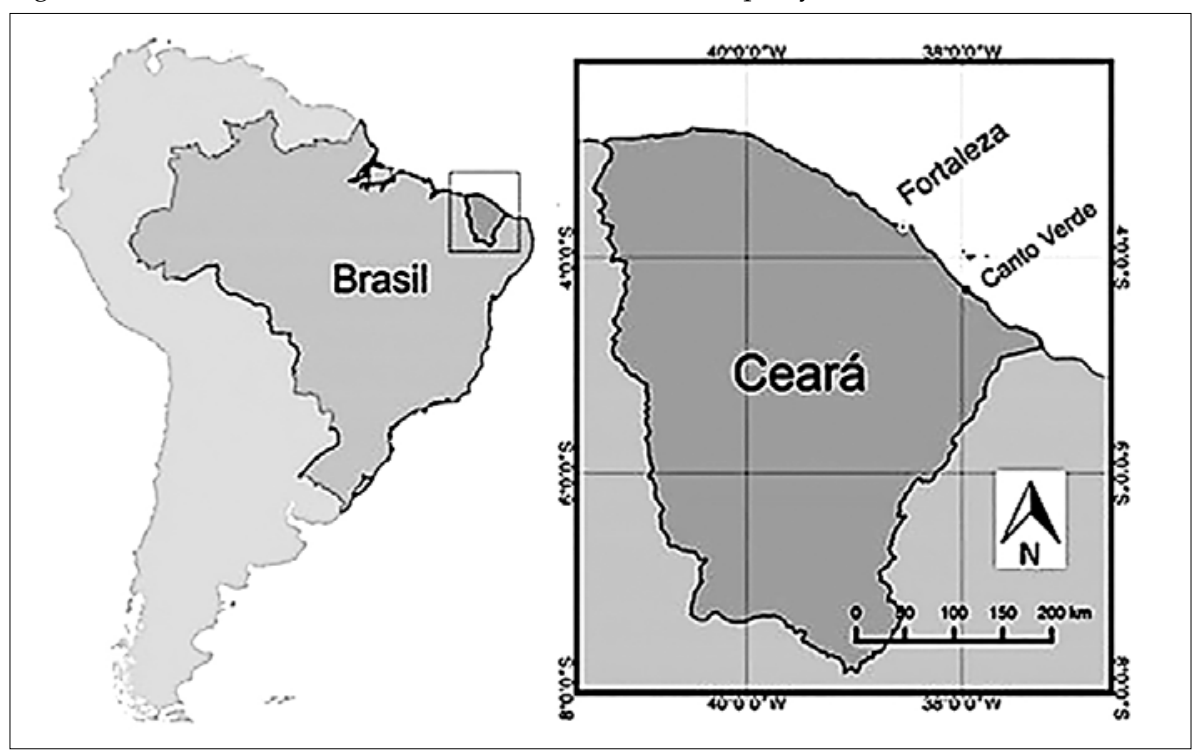


The regional climate of the coastal zone of Ceará is semiarid, which is predominant in Northeast Brazil, marked by two defined periods: one long and dry (from Month to Month), and another period short and humid (from month to month). The maximum temperatures range from $29.4^{\circ} \mathrm{C}$ (March) to $30.7^{\circ} \mathrm{C}$ (November), and minimum temperatures varying from $21.2^{\circ} \mathrm{C}$ to $23.7^{\circ} \mathrm{C}$ in the period between January and March (Morais, 2006).

According to Blankensteyn (2006), a single individual of ghost crab inhabits a burrow. Thus, measuring and counting the burrows of $O$. quadrata is an efficient method of population density analysis. Besides, as carapace width has a good correlation with burrow's diameter, it can be a reliable tool for estimating the age structure of the population (Schlacher et al., 2016). Thus, the present work adopted the presence and measures of the open burrows as indicative of the abundance and size of the crabs.

The densities of burrows were evaluated in each lunar phase (new moon, first quarter, full moon and third quarter) three times (12 samplings). Furthermore, the fieldwork was realized in the early morning ( $5 \mathrm{am}-7 \mathrm{am})$ as ghost crabs present peaks of activity during the dusk, night and dawn (Alberto \& Fontoura, 1999).

For each sampling day, eight transects (10 m wide x 65 long), $10 \mathrm{~m}$ apart, were demarcated perpendicular to the waterline. Such transects were delimited from $5 \mathrm{~m}$ below the high tide line to the limit of occurrence of burrows toward the dune (approximately 65 $\mathrm{m}$ long). Each transect was divided into 13 quadrats of $10 \times 5 \mathrm{~m}$ (Figure 2). The burrows inside transects were counted and the diameter was measured using a caliper with an accuracy of $\pm 0.1 \mathrm{~mm}$. The density of crabs was calculated considering the number of burrows within each quadrat.

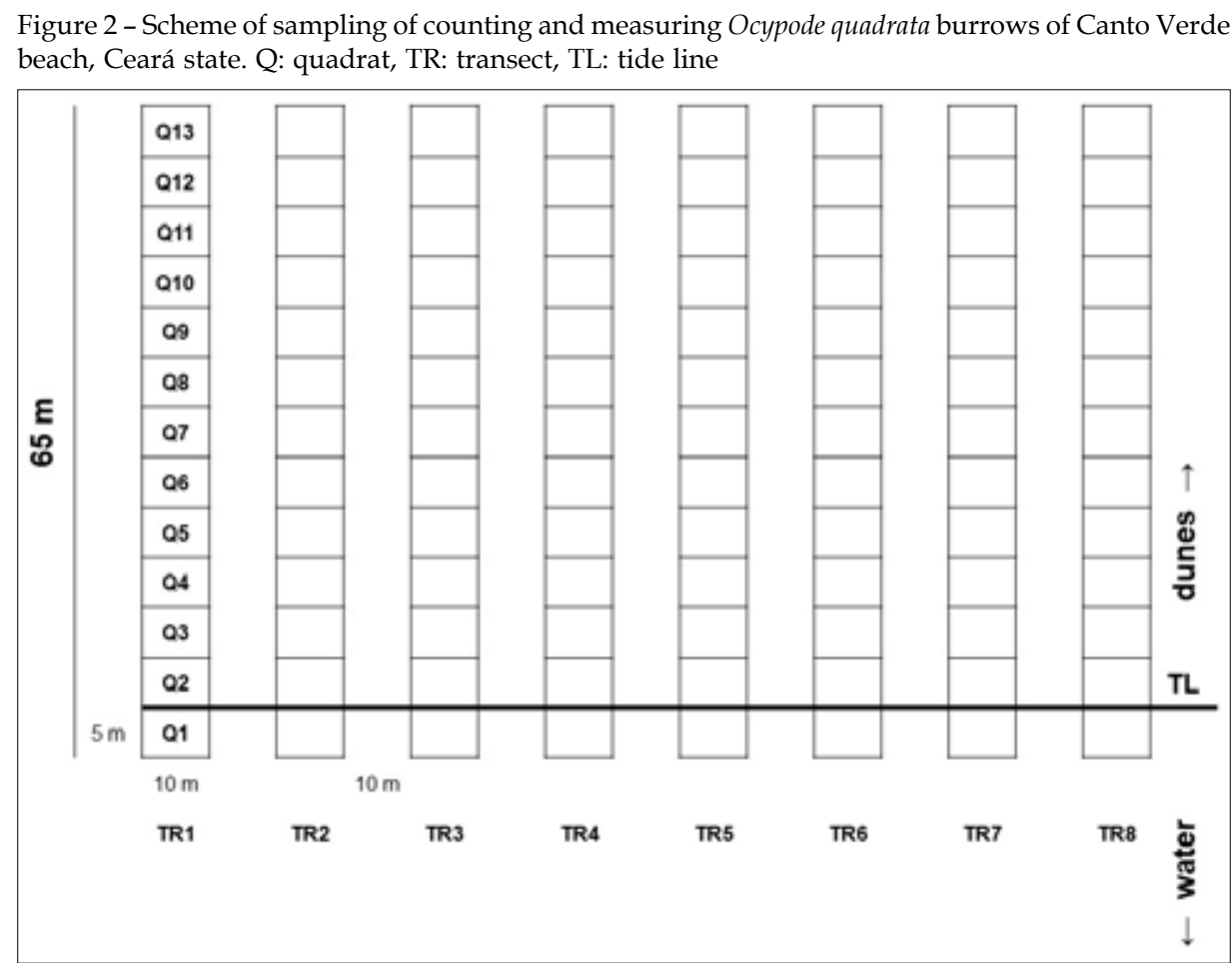

The tidal range and nocturnal luminosity were used to evaluate the effects of the lunar phase on the O. quadrata population of Canto Verde beach. The data were obtained in Tábua de Marés (2018), referring to the days when field observations were made. 
The density and diameter data of ghost crabs burrows did not meet the normality assumptions (Kolmogorov-Smirnov and Liliefors test) and homoscedasticity (Levene's test); therefore, non-parametric tests were performed. The lunar cycle and the vertical distribution along the beach were considered as independent variables ( $\mathrm{H}$ of KruskallWallis). The Spearman correlation test was performed to correlate the tidal range and lunar luminosity with the density and diameter of the burrows. All tests were executed using the Statistica software version 7.0.

\section{RESULTS}

\section{Variations of the lunar cycle}

During the lunar cycles, significant differences were observed between high tide height (Kruskal-Wallis test: $\mathrm{H}(3, \mathrm{~N}=1031)=801.3, \mathrm{p}=0.0)$ and low tide height (KruskalWallis test $\mathrm{H}(3, \mathrm{~N}=1031)=645.1222, \mathrm{p}=0.0)$ (Table I), where the highest amplitudes occurred in the spring tides and the lowest amplitudes in the neap tides. The highest values of nocturnal luminosity were observed during full moon (93 to 100\%), intermediate values during third quarter moon (36 to $71 \%$ ) and first quarter moon (25 to 67\%), and a near absence of light during new moon (0 to $5 \%$ ) (Table I). The luminosity that reaches the beach was significantly different between the observed lunar phases (Kruskal-Wallis test: $\mathrm{H}(11, \mathrm{~N}=1031)=1030.0, \mathrm{p}=0.000)$.

\begin{tabular}{|c|c|c|c|c|}
\hline Campaign & Moon Phase & $\begin{array}{l}\text { High Tide } \\
(\mathrm{m})\end{array}$ & $\begin{array}{c}\text { Low Tide } \\
(\mathrm{t})\end{array}$ & $\begin{array}{c}\text { Luminosity } \\
(\%)\end{array}$ \\
\hline 1 & $\begin{array}{l}\text { First quarter } \\
\text { moon }\end{array}$ & 3,2 & 0,4 & 25,0 \\
\hline 1 & Full moon & 3,4 & 0,3 & 93,0 \\
\hline 1 & $\begin{array}{c}\text { Third quarter } \\
\text { moon }\end{array}$ & 3,2 & 0,4 & 71,0 \\
\hline 1 & New moon & 3,3 & 0,4 & 5,0 \\
\hline 2 & First quarter & 3,0 & 0,7 & 59,0 \\
\hline 2 & Full moon & 3,0 & 0,4 & 100,0 \\
\hline 2 & $\begin{array}{l}\text { Third quarter } \\
\text { moon }\end{array}$ & 2,8 & 0,8 & 55,0 \\
\hline 2 & New moon & 3,6 & 0,3 & 0,0 \\
\hline 3 & $\begin{array}{l}\text { First quarter } \\
\text { moon }\end{array}$ & 2,6 & 1,0 & 67,0 \\
\hline 3 & Full moon & 3,4 & 0,1 & 95,0 \\
\hline 3 & $\begin{array}{l}\text { First quarter } \\
\text { moon }\end{array}$ & 2,9 & 0,8 & 36,0 \\
\hline 3 & New moon & 3,8 & $-0,1$ & 4,0 \\
\hline
\end{tabular}

\section{Density and diameter of burrows openings}

During the study period, 3846 O. quadrata burrows were observed with an average density of $0.061 \pm 0.09$ burrows $/ \mathrm{m}^{2}$ (Table II). The density of burrows varied significantly between lunar phases (Kruskal-Wallis test: $\mathrm{H}(3, \mathrm{~N}=1030)=9.5, \mathrm{p}=0.023)$. The highest densities occurred during the third quarter moon $\left(0.07\right.$ burrows $\left./ \mathrm{m}^{2}\right)$ and full moon $(0.06$ burrows $/ \mathrm{m}^{2}$, while the lowest densities were noticed during the first quarter moon $(0.5$ 
burrows / $\mathrm{m}^{2}$ ) and new moon (0.04 burrows / $\mathrm{m}^{2}$ ) (Figure 3). The mean diameter of the burrows was $20.8 \pm 12,3 \mathrm{~mm}$ (Table II) and it differs between the different moon phases. The highest values were noticed during the full moon, and the lowest values occurred during the new moon (Kruskal-Wallis test: $\mathrm{H}=16.63 ; \mathrm{p}=0.0008$ ) (Figure 3). Therefore, the average diameter of the burrows decreased gradually from full moon to new moon (Figure 4).

Table II - Density and mean diameter of the Ocypode quadrata burrows observed in each phase of the moon (first quarter, full, third quarter and new moon)

\begin{tabular}{cccc}
\hline Moon phase & Burrows (N) & DensityStandard/Deviation (burrows/m $\mathbf{m}^{2}$ ) & $\begin{array}{c}\text { Mean Diameter/Standard } \\
\text { Deviation (mm) }\end{array}$ \\
\hline First quater & 913 & $0.05 \pm 0.08$ & $20.53 \pm 11.62$ \\
Full moon & 1083 & $0.06 \pm 0.11$ & $22.32 \pm 13.66$ \\
Third quarter & 1139 & $0.07 \pm 0.11$ & $20.62 \pm 12.09$ \\
New moon & 711 & $0.04 \pm 0.06$ & $19.33 \pm 11.26$ \\
\hline Total & 3846 & $0.06 \pm 0.09$ & $20.84 \pm 12.34$ \\
\hline
\end{tabular}

Figure 3 - Average densities of Ocypode quadrata burrows during the lunar cycle on Canto Verde beach, Beberibe, Ceará state, Brazil
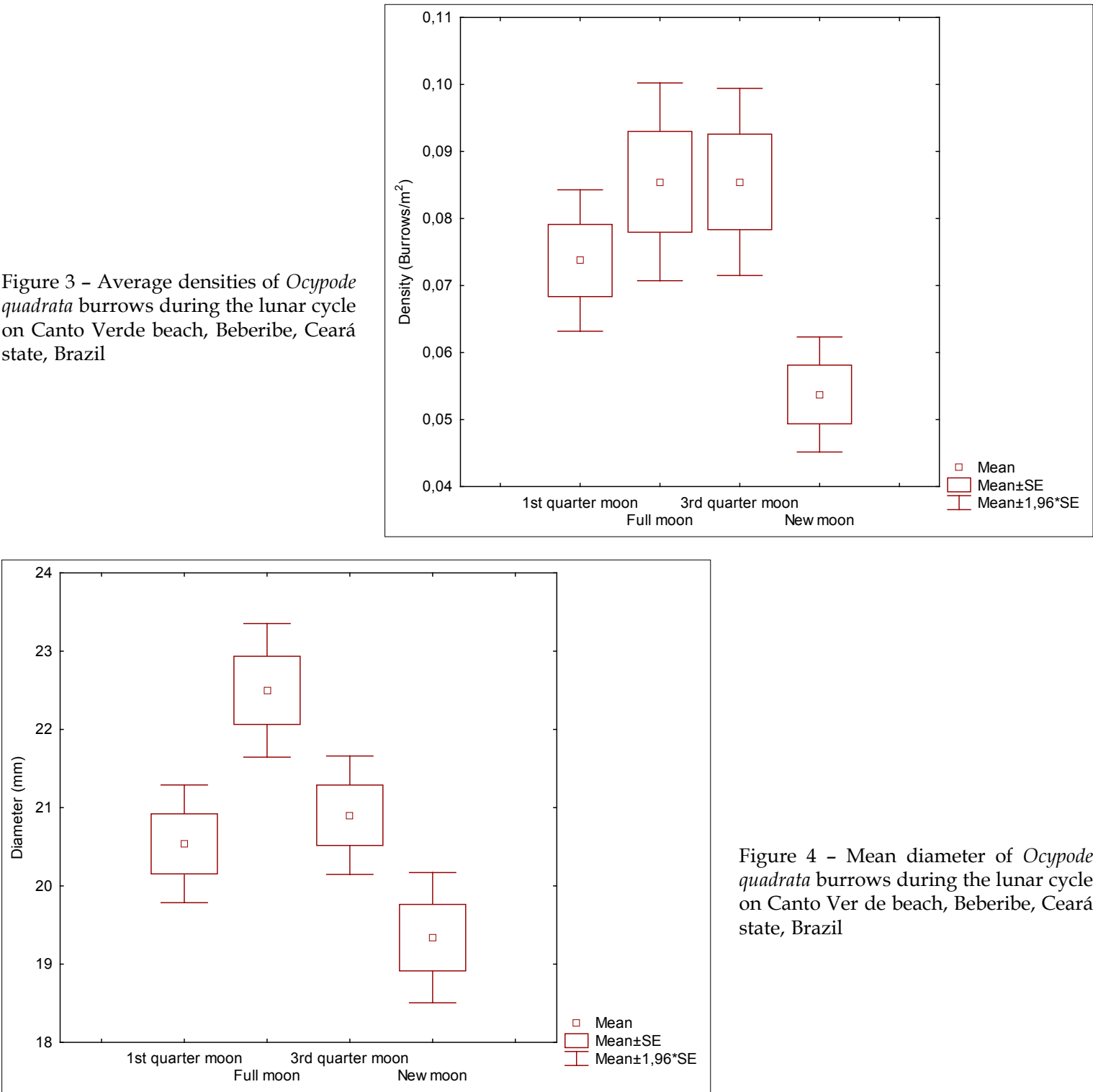

Figure 4 - Mean diameter of Ocypode quadrata burrows during the lunar cycle on Canto Ver de beach, Beberibe, Ceará state, Brazil 
Considering the distribution of O.quadrata burrows on the beach profile, the highest density of burrows was detected on the first three quadrats, which corresponded to the boundary between the intertidal zone and the supralittoral zone. Therefore, it occurred a decrease in the density of burrows toward the dunes. The density on such quadrats varied according to the lunar phase. The highest densities were observed during the full and third quarter moon, and the lowest densities were observed during the new and first quarter moon. Moreover, throughout a lunar cycle, the highest density was noticed on quadrat 2 due it is close to the water but not reached by the waves (Figure 5).

Figure 5 - Distribution of Ocypode quadrata burrows on the beach profile of Canto Verde beach, Ceará state, Brazil, considering the four moons (a) first-quarter moon; (b) full moon; (c) third-quarter moon and (d) new moon
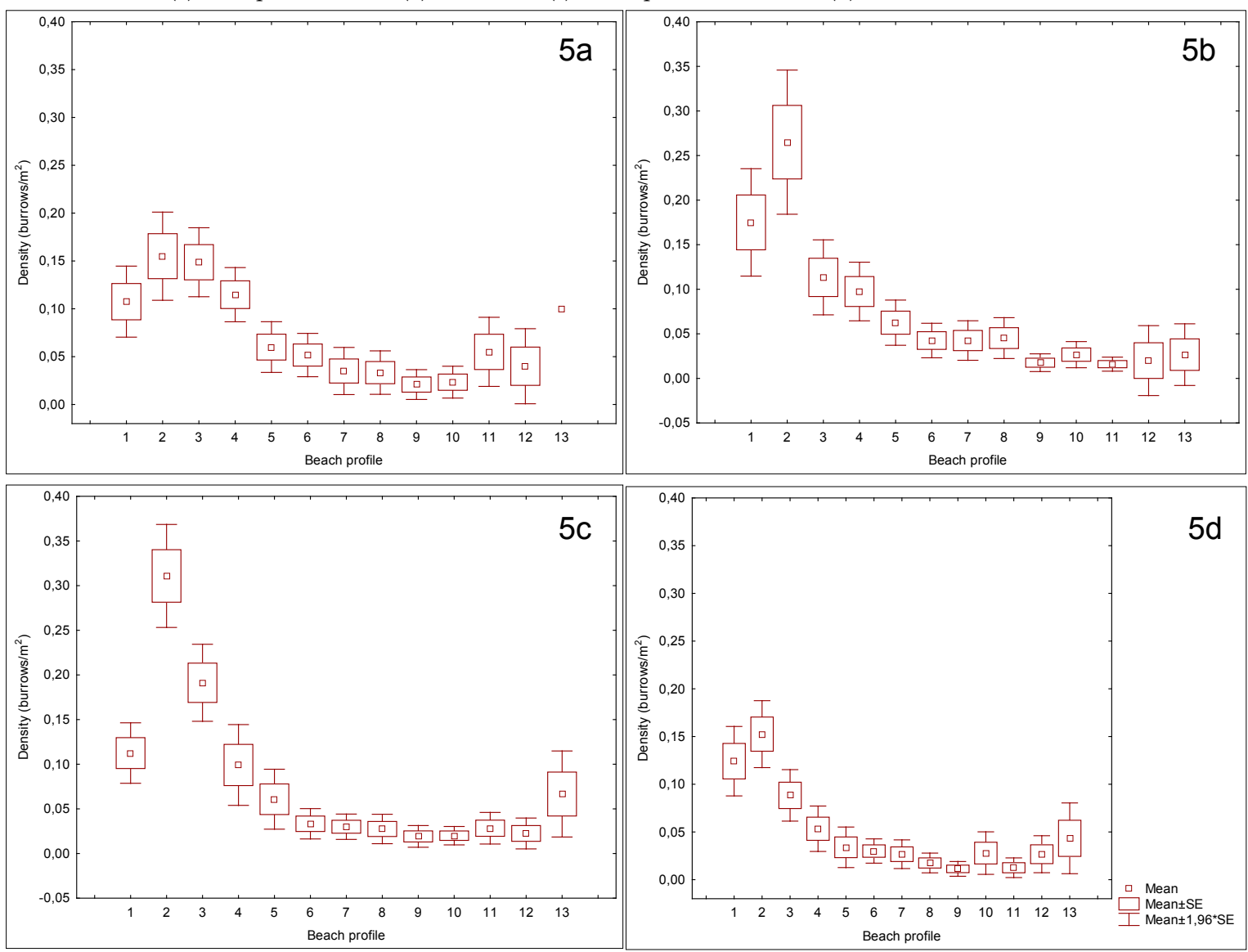

Figure 6 - Distribution of Ocypode quadrata burrows on the beach profile of Canto Verde beach, Ceará state, Brazil

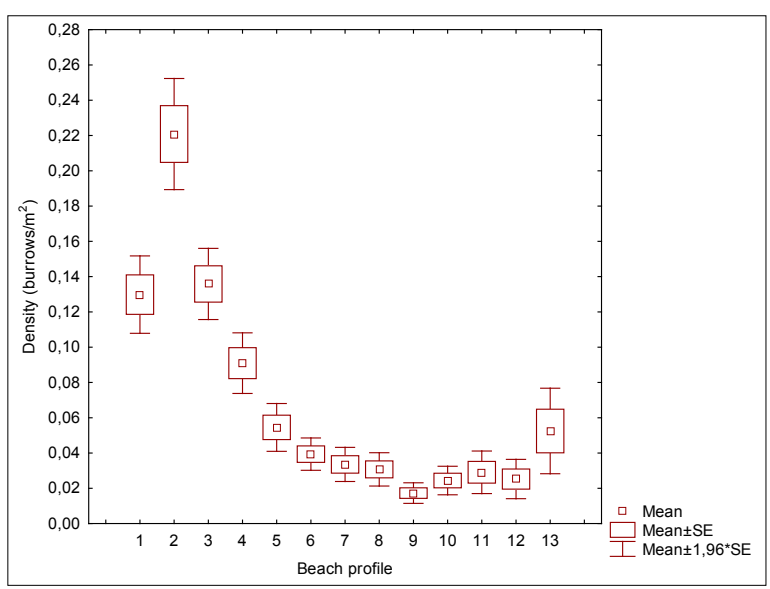


Considering the diameter of the opening of the burrow, during the moon phases which the nocturnal luminosity was higher (first-quarter and full moon), it was possible to observe differences in the distribution of the active burrows on the beach (Kruskal-Wallis test: $\mathrm{H}(3, \mathrm{~N}=3840)=16.62 \mathrm{p}=0.0008)$. The burrows with smaller diameter were observed closer to the intertidal zone, while the burrows with larger diameter predominated towards the dunes (Figures 7a and 7c). However, during moon phases with low light intensity (third-quarter moon and new moon), such pattern of size class distribution was not so evident due a higher rate of maintenance of burrows of large crabs that live close to the waterline (Figure $7 \mathrm{~b}$ and $7 \mathrm{~d}$ ).

Figure 7 - Distribution of size class of Ocypode quadrata burrows diameter on the beach profile of Canto Verde beach, Ceará state, Brazil, during the four moons phases (a) first quarter moon, (b) full moon; (c) third-quarter moon; and (d) new moon

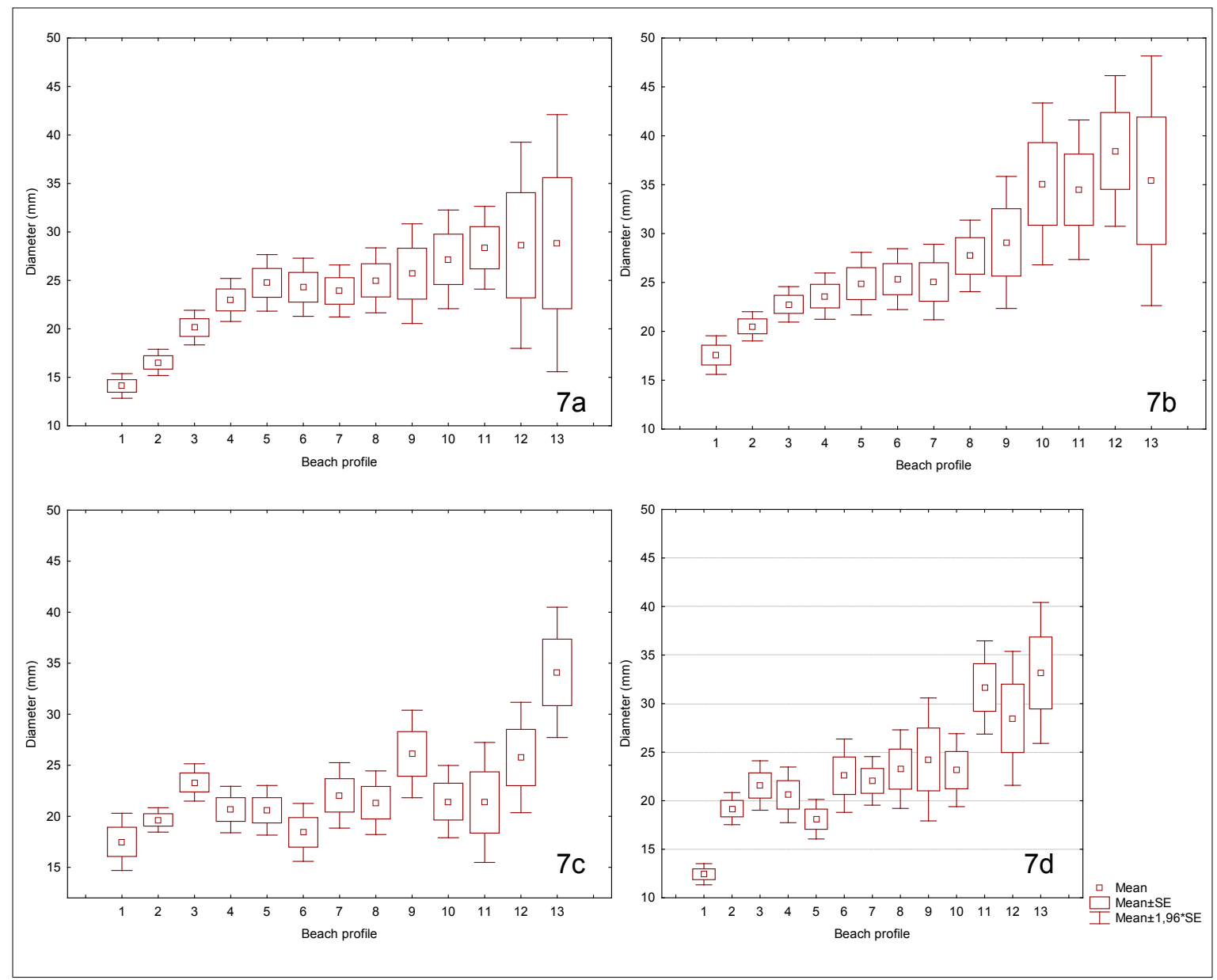

\section{Effects of the moon phases on the density and diameter of open burrows}

The effects of tidal range and night light had extremely weak correlations with the density and diameter of ghost crabs burrows (Table III). However, it was noticed a tendency of a positive influence of low tide and night luminosity on the density of crabs, besides a negative influence of high tide on the number of burrows. 
Table III - Spearman correlation between population parameters of Ocypode quadrata (Density and diameter of burrows) and abiotic parameters (tide range and nocturnal luminosity) on Canto Verde beach, Ceará state, Brazil. * Significant values $(\mathrm{p}<0.05)$

\begin{tabular}{cccc}
\hline & High Tide & Low Tide & Luminosity \\
\cline { 2 - 4 } Density of Burrows & $-0,14^{*}$ & $0,19^{*}$ & $0,11^{*}$ \\
Diameters of Burrows & $-0,07^{*}$ & $0,06^{*}$ & $0,06^{*}$ \\
\hline
\end{tabular}

\section{DISCUSSION}

Marine invertebrates, especially intertidal species, present rhythmic patterns of behavior (locomotion, feeding, breeding, and molting) responding to lunar and semilunar periodicities (Naylor, 2001). Such patterns are influenced by variations in tidal range, hydrostatic pressure, wave action, temperature and salinity (Naylor, 1982; Naylor \& Williams, 1984) as well as by lunar luminosity. This research demonstrates that lunar cycles influence the activity of the crab O. quadrata, varying the density, the diameter and the distribution of burrows on Canto Verde beach, due to tide conditions and nocturnal luminosity changes.

The temperature has been reported as an important driver of ghost crab activity. According to Haley (1972) and Lucrezi and Schlacher (2014), ghost crabs usually intensify burrows building during the warmest days. However, several authors (Steiner \& Leatherman, 1981; Blankensteyn, 2006; Alberto \& Fontoura, 1999) declare the nocturnal milder temperature conditions favor the ghost crabs activity. Moreover, Girão (2016) affirms that the high temperatures $\left(28^{\circ} \mathrm{C}\right.$ to $\left.42^{\circ} \mathrm{C}\right)$ of the sediment on the supralittoral of Ceará beaches can reduce ghost crab's activity during the day. Therefore, it is suggested that milder temperatures at night as well as nocturnal luminosity that is associated with the lunar cycle, influence the activities of such crabs.

Differences in beach extension in spring tide and neap tide were significant in Canto Verde beach. According to Pombo et al. (2017), ghost crabs perceive the tide lowering because of the decreasing of groundwater and moisture. Furthermore, the tidal movement influences crabs behavior. During tide lowering, the foraging area, and the nutritional resources, which were left by the previous high tide, increase. On the other hand, the high tide reduces the foraging area inducing the competition and the occurrence of agonistic events, which cause the refuge of crabs into their burrows. Therefore, the reduction of the density of burrows observed during the high tide period confirms the suggestion of Pombo et al. (2017).

According to several authors, luminosity controls circadian rhythms, migrations of pelagic organisms, and influences the ability of nocturnal predators to detect and capture prey (Lima \& Dill, 1989; Ringelberg, 1999; Bird et al., 2004). In the present study, the occurrence of crab burrows was greater in the brighter nights (full and waning). At full moon, which also has a greater variation on beach extension due to the spring tides, there was a high density of burrows. The density remained high also on the third quarter moon, but tended to decrease as the light emitted decreases. At the new moon (low light intensity), the number of crabs was low despite the high tide range. Thus, although no conclusive results have been obtained regarding the effect of nocturnal luminosity on the occurrence of $O$. quadrata burrows, significant variations of burrows densities along the lunar cycle can 
be attributed to a synergistic effect of the environmental conditions (tide variation, luminosity, and temperature).

Several authors highlight the visual acuity of Ocypode crabs. According to Rosenberg and Langer (2001), the rabdomers of compound eyes the Ocypode have the flexibility to respond to incident light, resulting in excellent visual sensitivity under different bright conditions. Probably such visual acuity is responsible for the high presence of crabs at night, especially adult specimens during the full moon.

The density of $O$. quadrata burrows may vary according to changes in beach characteristics and environmental factors (Girão, 2016). Under such variations, crabs take refuge in their burrows, covering their openings, which makes it difficult to see them (Alberto \& Fontoura, 1999; Turra; Gonçalves \& Denadai, 2005; Rosa \& Borzone, 2008). The low number of $O$. quadrata burrows observed in the present study $\left(0.061 \pm 0.09\right.$ burrows $\left./ \mathrm{m}^{2}\right)$ is probably due to the presence of covered burrows on the sampled area, since a low density of burrows was noted even in places where they commonly large concentrations occur.

Souza (2008) evidenced a high abundance of crabs population on the upper limit of high tide. Such concentration of burrows closer to the waterline is usually related to the source of food that was brought by the tides. Ghost crabs tend to occupy areas with a concentration of organic matter that strands on the beach; thus, the density of burrows decreases toward areas farther from the foraging zone (Borzone, 2008). Such pattern of distribution was also verified on the present study during all the lunar phases (Figure 6).

Concerning the diameter of burrows, the distribution varies along the lunar cycle, as well. Such fact indicates that juveniles tend to position themselves closer to the intertidal zone, while larger individuals are able to occupy upper areas. This observation reinforces the ontogenetic character of the distribution of such crabs (Milne \& Milne, 1946; Williams, 1984; Hill \& Hunter, 1973). Adults of O. quadrata can retain more moisture into their gill chambers than immature individuals; for this reason, they seem to be more resistant to high environmental temperatures and desiccation (Fisher \& Tevesz, 1979; Alberto \& Fontoura, 1999; Maia-Carneiro, 2013).

The largest diameters burrows open of O. quadrata were observed in the full moon, which indicates that larger crabs tend to be more active during this bright night period. The visual acuity of the crabs mentioned above could also explain the higher occurrence of adults at full moon. Although in full and new moon there are spring tides, which provide an increase of available intertidal area for the foraging, the burrowing activity seems to be influenced by nighttime brightness.

In the new and third quarter moons, the mean diameter of the open burrows noted closest to the high tide line presented relatively higher values than those ones in the first quarter and full moons. During dark nights, crabs are more restricted to the region near the debris zone; while, in the bright nights, crabs tends to migrate to places further away from this area. Such migration enlarges the foraging area, which decreases the competition for food. This behavior happens mainly with the larger animals and with greater capacity of displacement.

As previously mentioned, the populations of O.quadrata tend to increase the size and the diameters of the burrows from the water line towards the supralittoral. This work has shown that migrations along the lunar cycle related to light intensity. Moreover, the larger organisms construct their burrows furthest from the sea, mainly during bright nights, in an ontogenetic distribution. 


\section{CONCLUSIONS}

The lunar cycles influence the activity of the O. quadrata crab, varying the density, diameter, and distribution of the burrows on the Canto Verde beach due to changes in the tide conditions and nocturnal luminosity.

The occurrence of burrow construction and the distancing of larger animals from the sea was greater in the lunar phases that provided brighter nights. While, during dark nights, the density of burrows is reduced and larger organisms do not move much away from the sea, concentrating closer to the debris zone.

\section{BIBLIOGRAPHIC REFERENCES}

Schlacher, T.A.; Lucrezi, S.; Peterson, C.H.; Connoly, R.M.; Olds, A.D.; Althaus, F.; Hyndes, G.A.; Maslo, B.; Gilby, L.B.; Leon, J.X.; Weston, M.A.; Lastra, M.; Willians, A. \& Shoeman, D.S. Estimating animal populations and body sizes from burrows: Marine ecologists have their heads buried in the sand. Journal of Sea Research, v. 112, p. 55-64, 2016.

Alberto, R.M.F. \& Fontoura, N.F. Distribuição e estrutura etária de Ocypode quadrata (Fabricius, 1787) (Crustacea, Decapoda, Ocypodidae) em praia arenosa do litoral sul do Brasil, Revista Brasileira de Biologia, v. 59, p. 95-108, 1999.

Bird, B.L.; Branch, L.C. \& Miller, D.L. Effects of coastal lighting on foraging behavior of beach mice. Conservation Biology, v. 18, p. 1435-1439, 2004.

Blankensteyn, A. O uso de caranguejo maria-farinha Ocypode quadrata (Fabricius) (Crustacea, Ocypodidae) como indicador de impactos antropogênicos em praias arenosas da Ilha de Santa Catarina, Santa Catarina, Brasil. Revista Brasileira de Zoologia, v. 23, p. 870-876, 2006.

Chan, B.K.K.; Chan, K.K.Y. \& Leung, P.C.M. Burrow architecture of the ghost crab Ocypode ceratophthalma on a sandy shore in Hong Kong. Hydrobiologia, v. 560, p. 43-49, 2006.

Fisher, J.B. \& Tevesz, M.J.S. Within-habitat spatial patterns of Ocypode quadrata (Fabricius) (Decapoda Brachyura). Crustaceana, v. 5, p. 31-36, 1979.

Forward, J.R. \& Richard, B. Larval release rhythms of decapod crustaceans: an overview. Bulletin of Marine Science, v. 41, n. 2, p. 165-176, 1987.

Girão, M.M.L. Aspectos ecológicos do caranguejo-fantasma Ocypode quadrata Fabricius, 1787 (Brachyura-Ocypodidae) em praias arenosas do litoral cearense. Tese de doutorado, Programa de Pós-Graduação em Ciências Marinhas Tropicais, Universidade Federal do Ceará, 147 p., Fortaleza, 2016.

Hill, G.W. \& Hunter, R.E. Burrows of the ghost crab Ocypode quadrata (Fabricius) on the barrier islands, south-central Texas coast. Journal of Sedimentary Research, v. 43, p. 24-30, 1973.

Lima, S.L. \& Dill, L.M. Behavioral decisions made under the risk of predation: a review and prospectus. Canadian Journal of Zoology, v. 68 p. 619-640, 1989.

Lucrezi, S. \& Schalacher T.A. The ecology of ghost crabs. Oceanography and Marine Biology, Annual Review, v. 52, p. 201-256, 2014.

Maia-Carneiro, T.; Dorigo, T.A.; Andrade, L.G.; Gutiérrez-Cárdenas, P.D.A. \& Rocha, C.F.D. Density and spatial distribution of Ocypode quadrata (Decapoda, Ocypodidae) in an 
insular environment in the state of Rio de Janeiro, southeastern Brazil. Revista Brasileira de Zoociências, v. 15, n. 1, 2, 3, p. 91-96, 2013.

Mclachlan, A. \& Brown, A. The ecology of Sandy shores. New York, Academic Press. 373 p., 2006.

Morais, J.O.; Freire, S.S.G.; Pinheiro, S.L.; Sousa, N.J.M.; Carvalho, M.A.; Pessoa, S.R.P. \& Oliveira, M.H.S., p. 138-139, in Muehe, D. (org.). Erosão e progradação do litoral brasileiro. Ministério do Meio Ambiente, 475 p., Brasília, 2006.

Milne, L.J. \& Milne, M. Notes on the behavior of the ghost crab. The American Naturalist, v. 80, p. 362-380, 1946.

Naylor, E. Tidal and lunar rhythms in animals and plants. Biological Timekeeping, v. 14, p. 33-48, 1982.

Naylor, E. \& Williams, B.G. Environmental entrainment of tidally rhythmic behaviour in marine animals. Zoological Journal of the Linnean Society, v. 80, n. 2-3, p. 201-208, 1984.

Naylor, E. Marine animal behavior in relation to lunar phase. in Earth-Moon Relationships. Springer, Dordrecht, p. 291-302, 2001.

Oliveira F.K.D.S. \& Saraiva, M.D.F.O. Astronomia e astrofísica. Editora Livraria da Física, 5353 p., São Paulo, 2014.

Pombo, M.; Campagnoli, M.; Castilho-Martins, A.E. \& Turra, A. Continuous, videorecording assessment of daily activity cycle of the ghost crab Ocypode quadrata Fabricius, 1787 (Brachyura: Ocypodidae) in southeastern Brazil. Journal of Crustacean Biology, v. 38, p. 133-139, 2017.

Ringelberg, J. The photobehaviour of Daphnia spp. as a model to explain diel vertical migration in zooplankton. Biological Reviews of the Cambridge Philosophical Society, v. 74, p. 397-423, 1999.

Rosa, L.C. \& Borzone, C.A. Spatial distribution of the Ocypode quadrata (Crustacea: Ocypodidae) along estuarine environments in the Paranaguá Bay Complex, southern Brazil. Revista Brasileira de Zoologia, v. 25, p. 383-388, 2008.

Rosenberg, J. \& Langer, H. Ultrastructural changes of rhabdoms of the eyes of Ocypode species in relation to different regimes of light and dark adaptation. Journal of Crustacean Biology, v. 21 p. 345-353, 2001.

Schober, U.M. \& Christy, J.H. Sand disposal of the painted ghost crab Ocypode gaudichaudii (Decapoda: Ocypodidae): a possible role in courtship. Marine Biology, v. 116, p. 53-60, 1993.

Steiner, A.J. \& Leatherman, S.P. Recreational impacts on the distribution of ghost crabs Ocypode quadrata Fab. Biological Conservation, v. 20, p. 111-122, 1981.

Tábua de Marés. Disponível em: https:/ / tabuademares.com/br/ceara/beberibe/. Acesso em: nov. 2018.

Turra, A.; Gonçalves, M.A.O. \& Denadai, M.R. Spatial distribution of the ghost crab, Ocypode quadrata in low-energy tide-dominated sandy beach. Journal of Natural History, v. 39, p. 2163-2177, 2005.

Valero-Pacheco, E.; Alvarez, F.; Abarca-Arenas, L.G. \& Escobar, M. Population density and activity pattern of the ghost crab, Ocypode quadrata, in Veracruz, Mexico. Crustaceana, v. 80, p. 313-325, 2007. 
Welsh, J.H. The action of eyestalk extracts on retinal pigment migration in the crayfish, Cambarus bartoni. The Biological Bulletin, v. 77, p. 119-125, 1939.

Welsh, J.H. The sinus gland and 24 hours cycle of retinal pigment migration in the crayfish Cambarus bartoni. Journal of Experimental Zoology, v. 86, p. 35-49, 1941.

Williams, A.B. Shrimps, lobsters and crabs of the eastern United States, Maine to Florida. Washington, Smithsonian Institution Press, 550 p., 1984. 